\title{
Assessing hillslope sediment generation potential by tree throw: a preliminary field study along a small river valley in the Jura Mountains, northwest Switzerland
}

\section{Philip Greenwood, Jan Bauer, and Nikolaus J. Kuhn}

Physical Geography \& Environmental Change Research Group, Department of Environmental Sciences, University of Basel, Klingelbergstrasse 27, Basel-4056, Switzerland

Correspondence: Philip Greenwood (philip.greenwood@unibas.ch)

Received: 3 September 2020 - Revised: 25 May 2021 - Accepted: 28 May 2021 - Published: 14 July 2021

Abstract. A preliminary field-based investigation was undertaken in a small $\left(<10 \mathrm{~km}^{2}\right)$ river valley located in the mountainous Jura region of northwest Switzerland. The aims of the work were to assess sediment generation and annual sediment transport rates by tree throw on forested hillslopes and to document surface hydrology characteristics on four fresh tree throw mounds associated with recent tree throws over a $24 \mathrm{~d}$ monitoring period. For the tree throw mounds, average sediment recovery ranged from 7.7-28.2 g (dry weight), equivalent to a suspended sediment concentration of $145.2-327.8 \mathrm{~g} \mathrm{~L}^{-1}$, and runoff coefficients ranged from $1.0 \%-4.2 \%$. Based on a soil bulk density value of $1044 \mathrm{~kg} \mathrm{~m}^{-3}$, upslope runoff generation areas were denuded by an average of $0.14 \mathrm{~mm}$ within the $24 \mathrm{~d}$ monitoring period, representing an erosion rate equivalent to $2.1 \mathrm{~mm} \mathrm{a}^{-1}$. This means that a ca. $50 \mathrm{~cm}$ high tree throw mound could theoretically persist for around 200-250 years. For tree throw work, the dimensions of 215 fallen trees were measured and their locations mapped in 12 separate locations where tree throw was prominent along the river valley, representing a cumulative area equivalent to 5.3 ha (average density equivalent to 43 trees ha ${ }^{-1}$ ). The 215 tree throws generated a total of $20.1 \mathrm{~m}^{3}$ of fine sediment ( $<2 \mathrm{~mm} \mathrm{dia}$.), or the equivalent of $3.8 \times 10^{-4} \mathrm{~m}^{3} \mathrm{~m}^{-2}$. The process of tree throw was originally attributed to two extreme weather events that occurred across west and central Europe in late December 1999. Taking the 18-year period since both storms, this represents an annual sediment transport rate of $2.7 \times 10^{-5} \mathrm{~m}^{3} \mathrm{~m}^{-1} \mathrm{a}^{-1}$. Exploring the relationship with wind on fall direction, however, $65.5 \%$ of mapped tree throws $(n=143)$ generally fell in a downslope direction irrespective of hillslope aspect on which they were located. Given the similar fall orientation for most trees, this infers that severe storms may not have been responsible for the majority of tree throws, but instead, their upheave might be related to root failure. Given the relative maturity (average age 41 years) of fallen trees in this river valley, our data suggest that once trees attain a certain age, their physiognomy (i.e. height, mass, and centre of gravity) compromises their ability to remain securely anchored. We tentatively attribute this possibility to the presence of bedrock close to the surface, and to the shallow soil profile overlaying the steep rocky slopes. More in-depth studies are required to firstly confirm our findings, and secondly, tree throw studies should be undertaken in other Jura mountain river valleys to assess whether these results are representative. 


\section{Introduction}

Physical geography is a broad research discipline that serves to provide a window on varying environmental changes that have occurred over a wide range of spatial and temporal scales. Geomorphology represents a sub-discipline of physical geography that provides researchers with a means of determining how and possibly when Earth surface processes have affected the landscape and how those processes may impinge on how that landscape may be used in the future. This is done through the generation of knowledge on environmental processes and the subsequent dissemination of the positive or negative impacts that those processes may have on society and relevant stakeholders. One such landscape that is sensitive to environmental change is forests. Forest landscapes can experience stress for many reasons, be they climatic, biological, or anthropogenic, with the resultant net effect that, in the absence of external management, their sustainability over the longer term depends on the rate of tree regeneration exceeding the rate at which trees are lost, either by natural processes or by other factors.

The impact of a falling tree is not simply limited to the temporary loss of vegetation cover, but instead, tree throw, which is defined as the sudden upheave of roots, rock fragments, and soil as the tree falls over, can induce changes in varying surface processes that can influence localized hydrology and hence change the sediment dynamics of a given area, especially if notable areas of forest have been affected (Pawlik, 2013). The resultant increase in fine sediment (defined here as material $<2 \mathrm{~mm}$ dia. fraction composed of sand, silt, and clay) detached from the parent soil by tree throw represents a source of loose material that can increase rates of soil erosion, particularly on forested hillslopes where multiple trees have been upheaved simultaneously.

Tree throw can occur through natural mortality; environmental stresses such as, fire, disease, pestilence, or drought; or more commonly, storm events. During a storm, intense or prolonged rainfall can saturate the soil profile, resulting in larger trees becoming unstable. If this is combined with high wind and, for deciduous trees, a full-leaf canopy in summertime, a tree is then rendered susceptible to sudden upheave. When a tree falls, roots, rock fragments, and soil are usually upheaved as one unit, which is referred to as a root plate. After upheave, a number of distinct landscape features are created that include a tree throw pit, from which the root plate originates, and a tree throw mound, which, as the plate gradually weathers and disintegrates, consists of a mixture of rock fragments and fine sediment (Pawlik et al., 2016). The level of disturbance and hence the volume of material upheaved are attributed to many factors that include the age, size, and species of a tree; root depth and architecture; whether the tree was alive, dead, or decaying; and the depth of soil profile and textural characteristics and antecedent soil moisture content (Evarham and Brokaw, 1996; Schaetzl et al., 1988).
On hillslopes, the angle at which a tree falls relative to the steepest downslope gradient is also important in terms of sediment generation, as this controls where sediment from the root plate falls relative to the tree throw pit (Bobrovsky and Lyko, 2016). Fall direction of the tree is determined by local factors that include hillslope gradient and contour, soil profile depth, root depth and architecture, and prevailing wind speed and direction. Soil originating from a root plate of a tree that has fallen directly upslope (i.e. $180^{\circ}$ relative to the steepest gradient) will fall back into the tree throw pit, and net downslope migration of loose sediment will be zero. Alternatively, if a tree falls directly downslope (i.e. $0^{\circ}$ relative to the steepest gradient) sediment falling from the root plate will gradually accumulate on the downslope edge of the pit to form a tree throw mound. As a mound consists of a combination of rock fragments, root material, and loose fine sediment, a proportion of that fine material becomes vulnerable to downslope migration processes.

Despite the dominance of sudden tree throw as an ongoing sediment generation and detachment mechanism in forested environments, and thus an important geomorphic process that can influence hillslope evolution (Roering et al., 2010), whatever the cause of tree throw, knowledge of its effect on erosion rates is relatively limited. Such a lack of information thus hinders making future predictions on landscape evolution and the sustainability of forests in the Jura Mountains, especially when the likelihood of shifting climatic patterns arising from global warming are considered. This investigation therefore seeks to redress this information shortfall by (1) providing a first approximation of both sediment detachment volumes attributed to tree throw and the downslope migration of the detached sediment along a small river valley in the Jura Mountain range (northwest Switzerland), (2) quantifying rates of erosion from fresh tree throw mounds associated with recent tree throws, and (3) gaining an improved understanding of fine-sediment dynamics within a typical forested river valley in the Jura Mountains.

\section{Materials and methods}

\subsection{The Jura Mountain range}

The Jura Mountains are a subalpine range located to the north of the western Alps and straddle the border between Switzerland and France. They extend from a northeasterly to southwesterly arc, from northwest Switzerland, and terminate approximately $200 \mathrm{~km}$ to the south, representing a total area $>22000 \mathrm{~km}^{2}$ (Burnand, 1990). With a minimum elevation of ca. $200 \mathrm{~m}$ a.s.l. and a maximum elevation of $1720 \mathrm{~m}$ a.s.l., the landscape in the Jura mountain region is heavily dissected by many now geomorphologically under-fit streams that have incised down through the limestone bedrock since the last glaciation to form myriad small sub-catchments (Greenwood and Kuhn, 2014; Greenwood et al., 2018). The central part of the Jura Mountains forms a watershed that separates the 
Rhone and Rhine River catchments, with watercourses in the southern Jura draining into the Rhone system and those in the northern Jura draining into the Rhine system. The landscape is characterized by steep-sided valleys and narrow floodplains overlooked by exposed rock promontories.

Valley sides, although usually steep, are typically densely forested and support a mixture of European beech $(\mathrm{Fa}$ gus sylvatica), maple (Acer platanoides), Scots pine (Pinus sylvestris), and spruce (Picea spp.) (Greenwood and Kuhn, 2014). Soil type is classified as a rendzina, but the amount of fine substrate is often limited due to the rocky nature of the terrain, and fertility of the calcareous soil is inherently low (Burnand, 1990). The upper plateaux in the northern (Swiss) part of the Jura Mountains remains relatively undeveloped, with extensive agriculture in the form of fodder and hay production for small-scale cattle rearing representing the predominant land use.

\subsection{The study site}

The investigation was undertaken in a ca. $10 \mathrm{~km}^{2}$ catchment, known as Kaltbrunnental, situated approximately $20 \mathrm{~km}$ south of the city of Basel, in northwest Switzerland (coordinates: $47^{\circ} 25^{\prime} 09.80^{\prime \prime} \mathrm{N}, 07^{\circ} 34^{\prime} 24.19^{\prime \prime} \mathrm{E}$ to $47^{\circ} 25^{\prime} 46.38^{\prime \prime} \mathrm{N}$, $07^{\circ} 34^{\prime} 08.68^{\prime \prime} \mathrm{E}$ ) (Fig. 1). A more detailed description of Kaltbrunnental is provided in Greenwood and Kuhn (2014) and in Greenwood et al. (2018).

In brief, it is considered typical of other sub-catchments within the northern part of the Jura Mountains, with characteristic steep valley sides and narrow (i.e. frequently $<25 \mathrm{~m}$ wide) floodplains. A photographic montage showing the type of terrain on which the investigation was conducted can be seen in Fig. 2.

The valley is drained by a river known as the Ibach, which from source to confluence is ca. $10 \mathrm{~km}$ long and is generally orientated in a north-south direction (Fig. 1). Average catchment elevation on the valley bottoms is ca. $500 \mathrm{~m}$ a.s.l. (max. peak, ca. $980 \mathrm{~m}$ a.s.1.), and the climate is defined as temperate humid, with a mean maximum daily temperature of $25^{\circ} \mathrm{C}$ (August) in summer and a mean minimum daytime temperature of $-1{ }^{\circ} \mathrm{C}$ (January) in winter. Based on climate data recorded between 1980 and 2016 at the village of Grellingen, ca. $3 \mathrm{~km}$ northeast of the study catchment, average annual precipitation is ca. $1100 \mathrm{~mm}$ and average peak monthly precipitation at $99 \mathrm{~mm}$ typically occurs in May (Meteoblue, 2021). From late November until around March, low temperatures mean that precipitation often falls as snow where it can accumulate and linger until late March. The steep valley sides combined with the prominence of bedrock typically limits soil profile depth to $<40 \mathrm{~cm}$. Forests within Kaltbrunnental are prevalent on valley sides and mainly consist of F. sylvatica, interspersed with small, isolated stands of $P$. sylvestris. Whilst understorey vegetation is generally sparse to absent on the steeper upper valley sides, the lower hill-

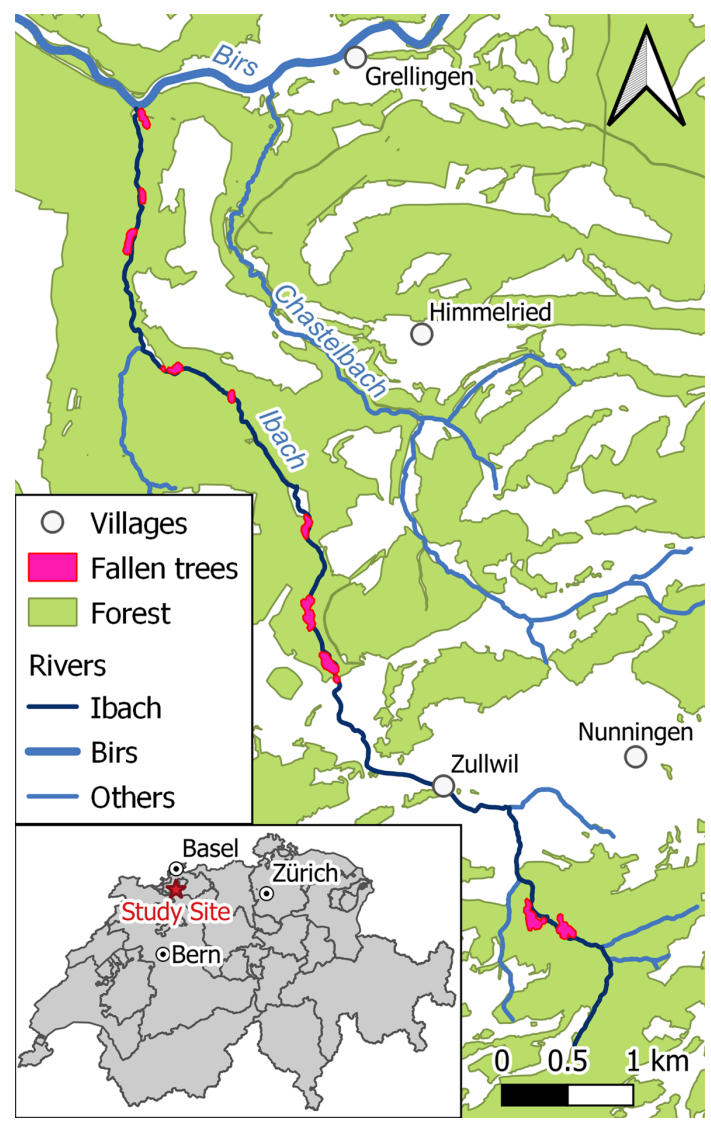

Figure 1. Map showing the location of the study site in northwest Switzerland, along with key boundaries and features within the chosen river valley.

slopes are usually covered with a notable layer of dead and decaying leaf litter.

Reasons for choosing this river valley arose whilst undertaking other longer-term sediment-related monitoring studies (see Greenwood and Kuhn, 2014 and Greenwood et al., 2018, 2019) which entailed regular fieldwork campaigns. During those site visits, the observed abundance of fallen trees, such as the cluster seen in Fig. 3; the apparent recurrence of tree throw; and the presumed level of lateral sediment connectivity between valley sides, narrow floodplains, and river channel (Fig. 2) (Fryirs et al., 2007) all provided motivation to undertake a preliminary investigation to quantify the effect of tree throw on sediment generation, which we define as the detachment of fine material from the parent soil by uprooting and the annual migration rate of the detached sediment.

Although most studies investigating tree throw focus on both coarse and fine material, we specifically focus only on the latter fraction (i.e. $<2 \mathrm{~mm}$ dia.) for three reasons. Firstly, its small physical size makes it highly mobile. Secondly, fine sediment carries exceptionally high concentrations of nutrients and contaminants (Walling et al., 2003) which, if entering nearby rivers and streams, can cause pollu- 


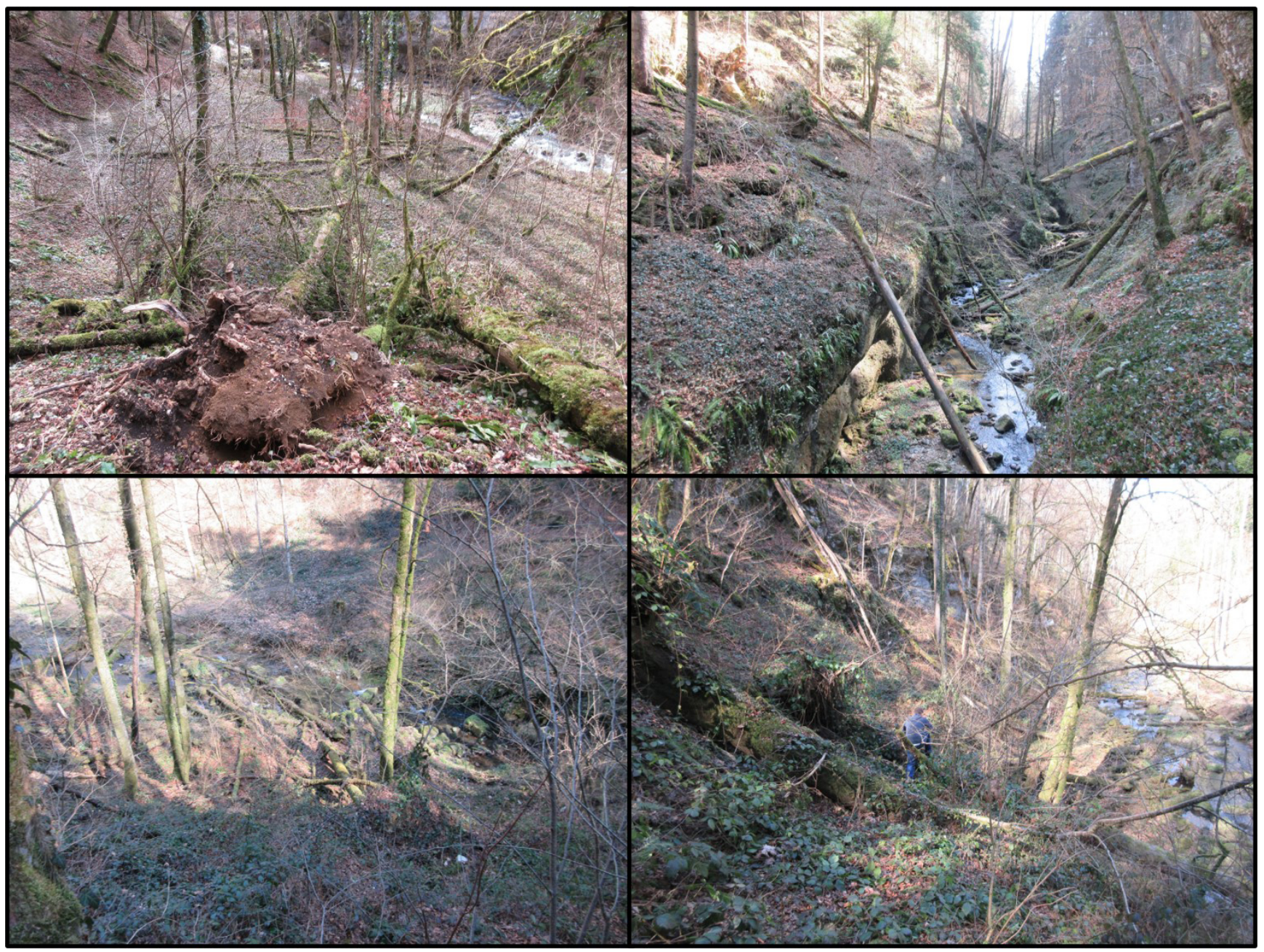

Figure 2. A photo montage showing varying geomorphic features and the type of terrain in which the tree throw investigation was undertaken.

tion and reduce water quality (Horowitz et al., 2012). Thirdly, the characteristically narrow floodplains (i.e. $<25 \mathrm{~m}$ wide) along the Ibach River offer limited opportunity for deposition of eroded sediment. From a geomorphological perspective, therefore, narrow floodplains have the potential to amplify the lateral connectivity that links valley sides to the river channel and increase the likelihood that a portion of the eroded sediment will enter the river, perhaps within seasonal timescales. Unlike other tree throw studies, we do not consider the upheaved brecciated rock fragments, as an absence of such material on cleared tracks and pathways at the base of valley sides indicated that this fraction was largely immobile, despite the steep slopes on which it occurs, presumably due to their angular and interlocking shapes.

\subsection{Field methods: assessing sediment mobility on recently formed tree throw mounds}

Intrigued by the abundance of tree throws, and inquisitive about their potential as a sediment generation mechanism,

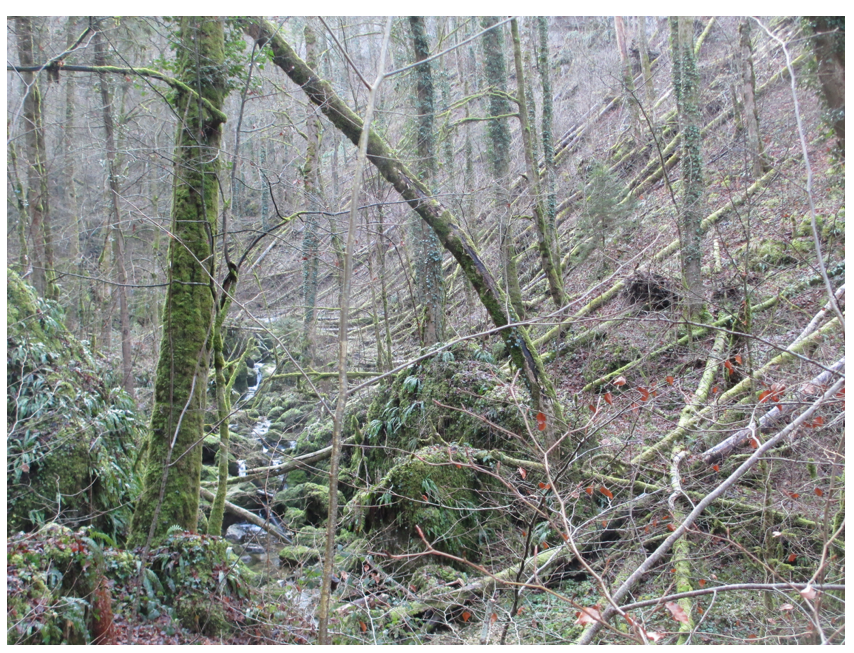

Figure 3. Uprooted trees located on an east-facing hillslope adjacent to the Ibach River in Kaltbrunnental catchment. 
a runoff trap was installed in October 2015 on a tree throw mound associated with four recent ( $<6$ month) tree throws. The four tree throw mounds were all considered recent topographic features for three reasons. Firstly, some tree throws still carried leaves from the previous summer growth. Secondly, residual plumes of fine sediment were readily visible downslope from each mound, and thirdly, established (i.e. rooted) vegetation was completely absent on each mound. Measurements of sediment mobilization were physically obtained using runoff traps, each of which was fabricated from two $38 \mathrm{~cm}$ wide $\times 15 \mathrm{~cm}$ long $\times 3 \mathrm{~cm}$ deep plastic trays, of the type ordinarily used to stand/water indoor plants in. The sidewall along the length of each tray was firstly cut away and removed to create an elongated opening. A trap was constructed by presenting a pair of trays together, top-to-top, with the cutaway portion creating a narrow opening, which was designed to allow runoff and sediment to freely enter, but keep out any form of precipitation. Once assembled, the remaining edges of each tray were sealed with bathroom silicon gel to form a watertight seal. Ordinary elastic bands were then carefully bound around the length and width of each trap for added strength and stability and also to facilitate rapid ease of access when recovering runoff and associated sediment during site visits. Once assembled, each runoff trap was then embedded at the base, and on the down-valley side of a tree throw mound, flush with the soil surface, with the cutaway opening facing upslope. Traps were then held in place using a series of wooden pegs driven into the soil profile immediately downslope of each trap, to prevent downslope movement of the trap itself. As an added measure, each trap was also carefully weighted down with rocks to prevent disturbance by wind or animals. The above configuration and the upslope runoff generation area can be seen in Fig. 4.

Tree throw mound characteristics were documented and included the angle of repose, which we use as a proxy for and hereafter refer to as mound gradient, upslope length, and runoff generation area immediately upslope of each runoff trap. Cumulative rainfall was recorded between site visits using an automated EM50 data logger $\left(\mathrm{ECH}_{2} \mathrm{O}\right.$ System; Meter Group, USA), which was installed away from the tree canopy but central to the study area. A total of four site visits were made (not including trap installation), and the time interval between visits ranged from 3 to $14 \mathrm{~d}$ ( $24 \mathrm{~d}$ total) depending on the amount of rainfall received. The resultant data were used to estimate runoff coefficients (\%) and quantities of recovered sediment, expressed as both (dry) mass (g) and equivalent suspended sediment concentration (SSC) $\left(\mathrm{g} \mathrm{L}^{-1}\right)$.

\subsection{Field methods: mapping tree throws}

Field walking was initially undertaken along the length of the Ibach to identify candidate areas. Twelve areas were identified, all of which were located within the Ibach River valley, which, from the perspective of sediment connectivity and migration, meant that they were directly geomorphologically

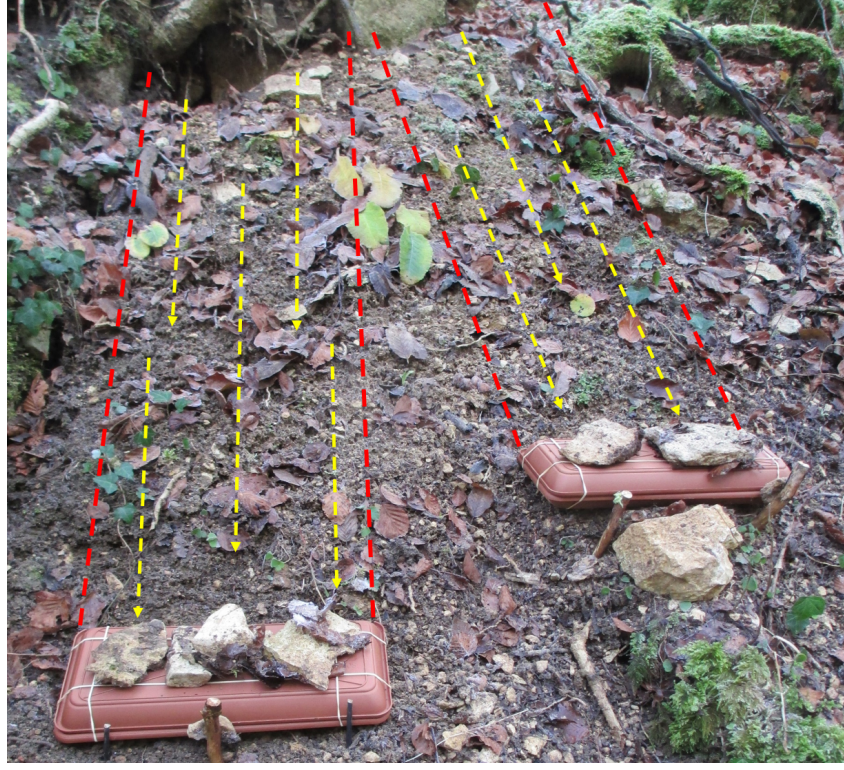

Figure 4. Sediment traps were positioned at the base of fresh tree throw mounds on the down-valley side and affixed using wooden pegs and stone weights. Upslope runoff generation areas are depicted as red dashed lines, and possible flow paths are depicted as yellow dashed arrows.

linked to the river (Fryirs et al., 2007). Importantly, most (i.e. $95 \%$ ) of the tree throws that could be safely accessed and mapped without using specialized safety equipment were located within these sites. The remaining $5 \%$ of tree throws located on slopes that were either too steep, or too close to vertical cliff edges were considered too dangerous to access and were thus not mapped. Hillslope aspect was determined for all sites using a standard field compass, and individual tree throws were mapped following a combination of general field protocols described in Gallaway et al. (2009) and Hellmer et al. (2015).

Mapping initially involved recording the coordinates of each fallen tree using a GPS (Swiss Coordinate System: $\mathrm{CH} 1903+)$. Individual tree throw dimensions were recorded and included height, width, and depth of the root plate, and tree trunk diameter measured $1.5 \mathrm{~m}$ from the base of the trunk (hereafter referred to as "diameter at breast height" or DBH). The DBH measurements enabled the circumference of the trunk to be established and in turn provided a means of approximating the age of a tree at the time it fell using a method established by Mitchell (1974) for ageing trees in northwest Europe. Although this represents a very basic yet rapid technique, it was considered appropriate for this preliminary investigation, but we acknowledge that it does not take into account localized environmental controls that govern individual tree growth, or other factors such as inter- and intraspecific competition between neighbouring trees (Schweingruber, 2007). Given these potential shortcomings, we em- 
phasis, therefore, that ages of tree throws represent first approximations only.

Other documented parameters included hillslope gradient at the location of each tree throw and the angle of (fall) obliquity relative to the direct downslope gradient. In situ soil bulk density (BD) measurements $(n=36)$ were taken at hillslope sites, at depths ranging from $10-40 \mathrm{~cm}$ in the soil profile in order to convert estimates of sediment transport volume $\left(\mathrm{m}^{3}\right)$ to equivalent mass $\left(\mathrm{kg} \mathrm{m}^{-3}\right)$.

On tabulating the acquired data, a first step was to establish the area of each site. This was achieved by overlaying GPS coordinates for each tree throw onto relevant topographic maps displayed in a Geographical Information System (GIS) (ArcGIS, version 10.3; Environmental Systems Research Institute ESRI). A polygon was drawn around tree throws in each mapped location and those located at the periphery of the main cluster were used as boundaries by which the area of each polygon was calculated. The second analytical step involved determining the root plate volume of tree throws. These were estimated using the half-ellipsoid model originally developed by Denny and Goodlet (1956) and latterly used by both Norman et al. (1995) and Gallaway et al. (2009) and which included brecciated rock fragments, root material, and soil pore space, as well as fine-sediment fraction. As only the latter portion is of interest to this investigation, field observations made at the time of mapping suggested we should conservatively attribute a nominal $25 \%$ of a total root plate volume to fine sediment, which is estimated using Eq. (1):

$V_{\mathrm{S}}=0.25 \times V_{\mathrm{RP}}$,

where $V_{\mathrm{S}}$ is the volume of detached fine sediment $\left(\mathrm{m}^{3}\right)$, and 0.25 is the proportion of fine sediment attributed to the total root plate volume $V_{\mathrm{RP}}\left(\mathrm{m}^{3}\right)$.

Sediment transport distance was calculated using a geometric approach adopted by both Gabet et al. (2003) and Hellmer et al. (2015), which is described in Eq. (2):

$X_{\mathrm{d}}=W / 2(\cos \theta+\sin \theta)+D / 2(\sin \theta-\cos \theta)$,

where $X_{\mathrm{d}}$ is downslope sediment transport distance (m), $\theta$ is the hillslope gradient $\left({ }^{\circ}\right)$, and $W$ and $D$ represent the width and depth (m) of the root plate, respectively. As Eq. (2) determines maximum sediment transport generated by a tree falling directly downslope, it was necessary to account for tree throws falling oblique to the downslope gradient. Values for $X_{\mathrm{d}}$ were thus modified, where required, using Eq. (3):

$d=\left(\left|180^{\circ}-\alpha\right|\right) \frac{X_{\mathrm{d}}}{180^{\circ}}$,

where $d$ is the modified sediment transport distance value $(\mathrm{m})$, and $\alpha$ is the oblique fall direction $\left(^{\circ}\right)$. If a tree falls directly upslope, fall direction $\alpha=180^{\circ}$, and sediment transport $d=0$, as this approach assumes that all upheaved sediment will return to the tree throw pit. By contrast, when a tree falls directly downslope, $\alpha=0^{\circ}$ and $d=X_{\mathrm{d}}$.
In a final stage, sediment transport rate was calculated using a similar model as Hellmer et al. (2015) and which is described in Eq. (4):

$q_{\mathrm{S}}=\sum\left(V_{\mathrm{S}} d\right) /(A t)$,

where $q_{\mathrm{S}}$ is the sediment transport rate $\left(\mathrm{m}^{3} \mathrm{~m}^{-1} \mathrm{a}^{-1}\right), A$ is the mapped area $\left(\mathrm{m}^{2}\right)$, and $\mathrm{t}$ is the time interval (years) required to uproot the number of mapped tree throws. As this study represents a preliminary assessment of sediment generation potential by tree throw, we present sediment detachment and transport rates for individual mapped areas in order to provide an indication of localized detachment rates which may be related to topographic or other environmental factors (Mitchell, 2013). Further to this, as the timing of individual tree throws in Kaltbrunnental is not known, we apply a time interval of $t=18$ years (i.e. 1999), as this corresponds with the elapsed period between when this study was conducted (2017) and two extreme weather events that swept across west and central Europe on 26 and 28 December 1999, referred to as Storms Lothar and Martin, respectively. We hypothesize that exceptionally high winds during these two storms acted as a detachment "trigger" that initiated tree throw, which in turn upheaved and liberated fine sediment from the soil profile, thus rendering it vulnerable to varying downslope migration processes (Constantine et al., 2012). Those processes considered most important in this catchment include diffusive soil creep (Martin, 2000; Hellmer et al., 2015), raindrop-impact-induced displacement (Kinnell, 2005; Gallaway et al., 2009; Geißler et al., 2012), rainfallgenerated surface runoff (Greenwood and Zhang, 2020), and freeze-thaw and snowmelt (Hayhoe et al., 1993).

In terms of storm magnitude, the Saffir-Simpson scale, which is commonly used to measure storm intensities in tropical regions, estimated Storms Martin and Lothar as weak and moderately strong hurricanes, respectively. Based on European wind-storm records for the last century, Storm Lothar was estimated to be a once-in-100-years event, and Storm Martin a once-in-50-years event (EQE Consulting, 2021). In the northern Jura region, including our study catchment, sustained gusts $>49 \mathrm{~m} \mathrm{~s}^{-1}\left(175 \mathrm{~km} \mathrm{~h}^{-1}\right)$ were recorded during both storms, resulting in the premature loss of between 5$15 \mathrm{~m}^{3} \mathrm{ha}^{-1}$ of timber due to tree throw (Bründl and Rickli, 2002). We do not average sediment generation and migration rates across equivalent storm return frequencies because, firstly, no storm events of a similar magnitude have occurred since 1999. Secondly, soil creep operates constantly under gravity and works in tandem with precipitation-driven erosive events which are recurrent in this region, with multiple events often taking place each month (Ledermann et al., 2008), making their relative erosivity magnitude too numerous to document individually. 


\section{Results}

\subsection{Erosion of tree throw mounds}

The slope gradient of the four tree throw mounds ranged from $35-56^{\circ}$ (ca. $71 \%-147 \%$ ), slope length immediately upslope of each runoff trap ranged from $0.45-1.6 \mathrm{~m}$, and runoff generation areas corresponding with the width of the runoff trap and up to the uppermost part of the tree throw mound ranged from $0.17-0.61 \mathrm{~m}^{2}$. Cumulative rainfall between visits was $15,17,19.1$, and $5 \mathrm{~mm}$ for site visits $1-$ 4 , respectively. Runoff and sediment, including the organic fraction, were recovered from all traps during all four visits, and key results are listed in Table 1. Data from the four traps were averaged per site visit, and the mass of recovered sediment (dry) ranged from 7.7-28.2 g. Sediment recovery values were converted to equivalent $\mathrm{SSC}$ and ranged from $145.2-327.8 \mathrm{~g} \mathrm{~L}^{-1}$. Runoff coefficients ranged from $1.0 \%-$ $4.2 \%$. Based on data from all four traps over all site visits, a weak direct correlation was obtained between sediment recovery $(\mathrm{g})$ and percent runoff coefficient $\left(r^{2}=0.15\right)$, which was not significant at the $95 \%$ confidence level, and a moderately strong direct correlation $\left(r^{2}=0.77\right)$ was obtained between sediment recovered $(\mathrm{g})$ and equivalent $\operatorname{SSC}\left(\mathrm{g} \mathrm{L}^{-1}\right)$, which was significant at the $95 \%$ confidence level. Based on the cumulative amounts of sediment recovered from each tree throw mound over the $24 \mathrm{~d}$ monitoring period, using a BD of $1044 \mathrm{~kg} \mathrm{~m}^{-3}$, we estimate that the soil surface of the four mounds for the upslope areas where measurements were taken was denuded by an average of $0.14 \mathrm{~mm}$, or the equivalent of $2.1 \mathrm{~mm} \mathrm{a}^{-1}$. Given the prominence of tree throw mounds above the soil surface and their exposure to a large range of degradation processes (Martin et al., 2013), we assume this rate of erosion is likely to be applicable over the entire surface of each fresh tree throw mound.

\subsection{Mapped tree throw sites: descriptive statistics}

Tree throws were mapped in 12 discrete areas (hereafter referred to as Sites a-1) along the Ibach River valley where most tree throws were located. Key descriptive site characteristics are listed in Table 2. Mapped areas ranged from 0.15-0.90 ha, with a cumulative area equivalent to 5.3 ha. Median hillslope gradients of the 12 sites ranged from 27$40^{\circ}$, and the median gradient based on all sites was $35^{\circ}$. The dimensions and positions of 215 tree throws were mapped within the 12 sites, with tree throw densities ranging from an equivalent $22 \mathrm{ha}^{-1}$ (Site j) to $53 \mathrm{ha}^{-1}$ (Site c), with an average of $43 \mathrm{ha}^{-1}$. The volume of fine sediment generated by tree throw at each site ranged from $0.6 \mathrm{~m}^{3}$ (Sites $\mathrm{c}$ and $\mathrm{h}$ ) to $3.9 \mathrm{~m}^{3}$ (Site b). Cumulatively, the 215 tree throws generated $20.1 \mathrm{~m}^{3}$ of fine sediment within the 5.3 ha mapped area. Given limitations with the ageing technique outlined in the Methods section, the following ages presented in Fig. 5 represent very tentative estimates only, but range from 1-5 years

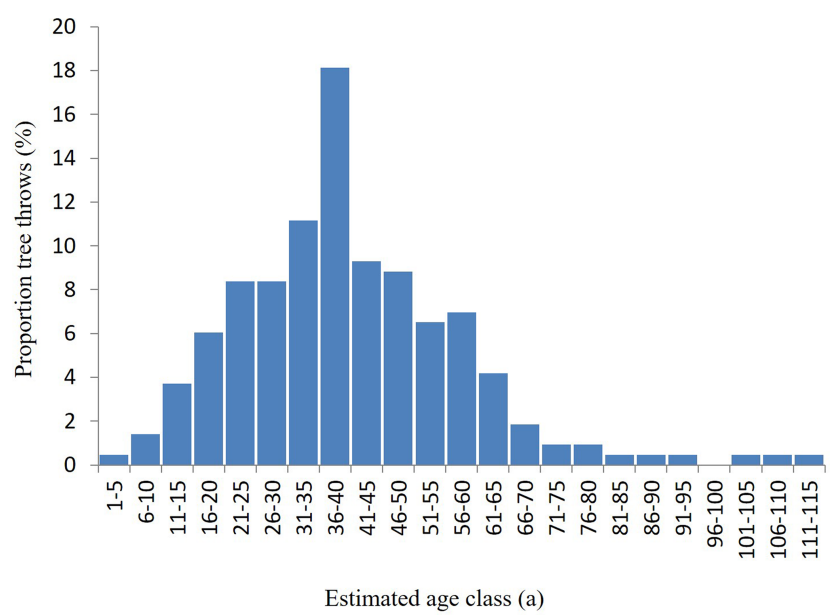

Figure 5. Estimated age frequency of mapped tree throws.

old $(0.5 \% ; n=1)$ to $111-115$ years old $(0.5 \% ; n=1)$ when upheave occurred.

Peak upheave occurred when trees were estimated at between $36-40$ years old $(18.1 \% ; n=39)$, and the average age at time of upheave was estimated at 41 years. The age range of standing trees was conservatively estimated to be at least 150 years, which contrasts with the 109-year age range of fallen trees (youngest 5 years and oldest 114 years). Based on the younger age range associated with tree throws, the tree throw dataset was positively skewed (1.27).

Tree throw fall directions, although recorded individually, were categorized for simplicity in four $90^{\circ}$ orientations: those that fell between $316-45^{\circ}$ (hereafter referred to as "downslope"), those that fell between 226-315 (left side of slope), those that fell between $46-135^{\circ}$ (right side of slope), and those that fell between 136-225 (upslope). Presented in this general configuration and expressed as percentages of the total number $(n=215)$, Fig. 6 reveals that $80.5 \%$ of all tree throws (173) fell downslope; $9.8 \%$ (21) and $7 \%$ (15) fell to the left and right of the slope, respectively; and just $2.8 \%$ (6) fell upslope.

\subsection{Sediment generation and transport rates by tree throw}

Incorporating relevant information into Eqs. (1)-(4), the $20.1 \mathrm{~m}^{3}$ of fine sediment generated within the 5.3 ha area represents a volume of soil equivalent to $3.8 \times 10^{-4} \mathrm{~m}^{3} \mathrm{~m}^{-2}$. Taking the 18-year period since Storms Lothar and Martin, when our assumption predicts that most trees were blown over, the average annual rate of sediment generation attributed to tree throw is estimated at $2.1 \times 10^{-5} \mathrm{~m}^{3} \mathrm{~m}^{-2} \mathrm{a}^{-1}$, or the equivalent of $2.2 \times 10^{-2} \mathrm{~kg} \mathrm{~m}^{-2} \mathrm{a}^{-1}$, using the same $\mathrm{BD}$ value stated above.

Entering relevant data into Eq. (4), average sediment transport volume of soil crossing a unit width of hillslope based on data from all 12 sites is estimated at $4.8 \times 10^{-4} \mathrm{~m}^{3} \mathrm{~m}^{-1}$. 
Table 1. Results of surface hydrology measurements using runoff sediment traps installed on four tree throw mounds, each under a recent tree throw.

\begin{tabular}{|c|c|c|c|c|c|c|c|c|c|c|c|}
\hline $\begin{array}{l}\text { Site } \\
\text { visit }\end{array}$ & $\begin{array}{l}\text { Runoff } \\
\text { trap } \\
\text { ID }\end{array}$ & $\begin{array}{r}\text { Angle } \\
\text { of repose } \\
\left({ }^{\circ}\right)\end{array}$ & $\begin{array}{r}\text { Slope } \\
\text { length } \\
(\mathrm{m})\end{array}$ & $\begin{array}{r}\text { Runoff } \\
\text { generation } \\
\text { area } \\
\left(\mathrm{m}^{2}\right)\end{array}$ & $\begin{array}{r}\text { Cumulative } \\
\text { rainfall } \\
(\mathrm{mm})\end{array}$ & $\begin{array}{r}\text { Sediment } \\
\text { recovery } \\
(\mathrm{g})\end{array}$ & $\begin{array}{r}\text { Average } \\
\text { sediment. } \\
\text { recovery } \\
(\mathrm{g})\end{array}$ & $\begin{array}{r}\text { Suspended } \\
\text { sediment } \\
\text { concentration } \\
\left(\mathrm{g} \mathrm{L}^{-1}\right)\end{array}$ & $\begin{array}{r}\text { Average } \\
\text { suspended } \\
\text { sediment } \\
\text { concentration } \\
\left(\mathrm{g} \mathrm{L}^{-1}\right)\end{array}$ & $\begin{array}{r}\text { Runoff } \\
\text { coefficient } \\
(\%)\end{array}$ & $\begin{array}{r}\text { Average } \\
\text { runoff } \\
\text { coefficient } \\
(\%)\end{array}$ \\
\hline \multirow[t]{4}{*}{ First } & lus & 40 & 1.6 & 0.61 & 15 & 5.7 & 9.7 & 149.1 & 238.7 & 0.5 & 1.1 \\
\hline & $2 \mathrm{ds}$ & 56 & 0.45 & 0.17 & & 4.4 & & 104.2 & & 2.5 & \\
\hline & $3 \mathrm{~L}$ & 35 & 1.37 & 0.52 & & 21.2 & & 532.7 & & 0.6 & \\
\hline & $3 R$ & 38 & 1.3 & 0.49 & & 7.4 & & 168.7 & & 0.7 & \\
\hline \multirow[t]{4}{*}{ Second } & 1us & 40 & 1.6 & 0.61 & 17 & 9.0 & 9.3 & 86.3 & 178.1 & 1.1 & 1.3 \\
\hline & $2 \mathrm{ds}$ & 56 & 0.45 & 0.17 & & 7.1 & & 141.5 & & 2.6 & \\
\hline & $3 \mathrm{~L}$ & 35 & 1.37 & 0.52 & & 12.8 & & 323.5 & & 0.6 & \\
\hline & $3 R$ & 38 & 1.3 & 0.49 & & 8.3 & & 161.3 & & 0.7 & \\
\hline \multirow[t]{4}{*}{ Third } & lus & 40 & 1.6 & 0.61 & 19.1 & 8.5 & 7.7 & 66.5 & 145.2 & 1.3 & 1.0 \\
\hline & $2 \mathrm{ds}$ & 56 & 0.45 & 0.17 & & 6.3 & & 224.3 & & 1.3 & \\
\hline & $3 \mathrm{~L}$ & 35 & 1.37 & 0.52 & & 9.8 & & 171.8 & & 0.7 & \\
\hline & $3 R$ & 38 & 1.3 & 0.49 & & 6.3 & & 118.0 & & 0.7 & \\
\hline \multirow[t]{4}{*}{ Fourth } & lus & 40 & 1.6 & 0.61 & 5 & 62.1 & 28.2 & 540.7 & 327.8 & 4.3 & 4.2 \\
\hline & $2 \mathrm{ds}$ & 56 & 0.45 & 0.17 & & 6.4 & & 203.4 & & 5.5 & \\
\hline & $3 \mathrm{~L}$ & 35 & 1.37 & 0.52 & & 37.9 & & 467.3 & & 3.9 & \\
\hline & $3 R$ & 38 & 1.3 & 0.49 & & 6.4 & & 99.7 & & 3.1 & \\
\hline
\end{tabular}

Table 2. Key descriptive information associated with mapped tree throws in 12 surveyed areas in Kaltbrunnental. n/a stands for not applicable.

\begin{tabular}{|c|c|c|c|c|c|c|c|c|c|c|c|c|c|c|}
\hline Area ID & a & $\mathrm{b}$ & $\mathrm{c}$ & $\mathrm{d}$ & $\mathrm{e}$ & $\mathrm{f}$ & $\mathrm{g}$ & $\mathrm{h}$ & $\mathrm{i}$ & $\mathrm{j}$ & $\mathrm{k}$ & 1 & Total & Av. \\
\hline Surveyed area (ha) & 0.21 & 0.60 & 0.15 & 0.26 & 0.35 & 0.16 & 0.33 & 0.50 & 0.82 & 0.90 & 0.57 & 0.45 & 5.3 & $\mathrm{n} / \mathrm{a}$ \\
\hline Number of tree throws & 10 & 29 & 8 & 10 & 13 & 8 & 12 & 24 & 40 & 20 & 22 & 19 & 215 & $\mathrm{n} / \mathrm{a}$ \\
\hline Tree throw density $\left(\mathrm{ha}^{-1}\right)$ & 48 & 48 & 53 & 39 & 37 & 50 & 36 & 48 & 49 & 22 & 39 & 42 & $\mathrm{n} / \mathrm{a}$ & 43 \\
\hline Average slope $\left({ }^{\circ}\right)$ & 28 & 30 & 34 & 40 & 20 & 31 & 38 & 40 & 36 & 28 & 34 & 27 & $\mathrm{n} / \mathrm{a}$ & 32.2 \\
\hline Average trunk dia. $(\mathrm{cm})$ & 33 & 38 & 30 & 39 & 42 & 39 & 39 & 24 & 25 & 26 & 34 & 38 & $\mathrm{n} / \mathrm{a}$ & 33.9 \\
\hline Average trunk circum. $(\mathrm{cm})$ & 104 & 120 & 94 & 122 & 131 & 122 & 121 & 76 & 80 & 80 & 106 & 118 & $\mathrm{n} / \mathrm{a}$ & 106.2 \\
\hline Average estimated age (a) & 42 & 48 & 38 & 49 & 52 & 49 & 48 & 30 & 32 & 32 & 43 & 47 & $\mathrm{n} / \mathrm{a}$ & 41 \\
\hline Sub-total root plate volume $\left(\mathrm{m}^{3}\right)$ & 4.7 & 15.5 & 2.3 & 2.8 & 8.7 & 5.2 & 6.8 & 2.6 & 6.9 & 7.8 & 3.6 & 13.4 & 71.54 & 6.7 \\
\hline Sediment volume $\left(\mathrm{m}^{3}\right)$ & 1.2 & 3.9 & 0.6 & 0.7 & 2.2 & 1.3 & 1.7 & 0.6 & 1.7 & 2 & 0.9 & 3.3 & 20.1 & 1.7 \\
\hline
\end{tabular}

Again, dividing this value by the 18 -year period since Storms Lothar and Martin, the average annual sediment transport rate is estimated at $2.7 \times 10^{-5} \mathrm{~m}^{3} \mathrm{~m}^{-1} \mathrm{a}^{-1}$, or the equivalent of $2.8 \times 10^{-2} \mathrm{~kg} \mathrm{~m}^{-1} \mathrm{a}^{-1}$, using the same BD value reported earlier. A comparison of annual sediment transport rates, expressed as both volume and mass, is listed for all 12 sites in Table 3.

\section{Discussion}

\subsection{Erosion of tree throw mounds}

Surface hydrology measurements from a freshly formed tree throw mound under four recent tree throws revealed very low runoff coefficients (max. $\leq 4.2 \%$ ), but very high equivalent $\mathrm{SSC}$ values (max. $540.7 \mathrm{~g} \mathrm{~L}^{-1}$ ). For perspective, and by way of comparison, Greenwood et al. (2018) reported a SSC of $0.54 \mathrm{~g} \mathrm{~L}^{-1}$ for the Ibach River during high-flow conditions. The weak correlation between sediment recovery and percent runoff coefficient is interpreted as a strong indication that surface runoff did not play a significant role in mobilizing sediment on the fresh tree throw mounds. The significant correlation between sediment recovery and SSC is interpreted as evidence of the loose nature of the soil, resulting in high infiltration potential, both of which would inhibit incidences of runoff generation. Although the high SSCs indicate that fine sediment is extremely mobile, albeit at very localized spatial scales, the collective findings infer that surface runoff is not dominant in controlling downslope sediment displacement. Instead, we hypothesize that the naturally steep angle of tree throw mounds along with the un-compacted nature of the material and their exposed above-ground position all render fine sediment extremely vulnerable to downslope mobilization by processes other than surface runoff. Those processes under consideration most likely include diffusion and soil creep of loose material by gravity, combined with, and probably exacerbated by, varying mechanisms capable of physically dis- 
Table 3. Sediment transport rates by tree throw within 12 surveyed areas in Kaltbrunnental, expressed as volume and mass values.

\begin{tabular}{lrrrrrrrrrrrrr}
\hline Area ID & $\mathrm{a}$ & $\mathrm{b}$ & $\mathrm{c}$ & $\mathrm{d}$ & $\mathrm{e}$ & $\mathrm{f}$ & $\mathrm{g}$ & $\mathrm{h}$ & $\mathrm{i}$ & $\mathrm{j}$ & $\mathrm{k}$ & $\mathrm{l}$ & Av. \\
\hline $\begin{array}{l}\text { Sediment transport rate } \\
\text { Since Storms Lothar \& }\end{array}$ & 5.3 & 7.7 & 3.6 & 3 & 4.1 & 8.8 & 6.6 & 1.1 & 2.1 & 2.8 & 1.5 & 10.7 & 4.8 \\
Martin $\left(10^{-4} \mathrm{~m}^{3} \mathrm{~m}^{-1}\right)$ & & & & & & & & & & & & & \\
\hline $\begin{array}{l}\text { Volume sediment } \\
\text { Transport rate }\end{array}$ & 3 & 4.3 & 2 & 1.7 & 2.3 & 4.9 & 3.6 & 0.6 & 1.2 & 1.5 & 0.8 & 5.9 & 2.7 \\
$\left(10^{-5} \mathrm{~m}^{3} \mathrm{~m}^{-1} \mathrm{a}^{-1}\right)$ & & & & & & & & & & & & & \\
\hline $\begin{array}{l}\text { Mass sediment } \\
\text { Transport rate }\end{array}$ & 3.1 & 4.4 & 2.1 & 1.7 & 2.4 & 5.1 & 3.8 & 0.7 & 1.2 & 1.6 & 0.9 & 6.2 & 2.8 \\
$\left(10^{-2} \mathrm{~kg} \mathrm{~m}^{-1} \mathrm{a}^{-1}\right)$ & & & & & & & & & & & & & \\
\hline
\end{tabular}

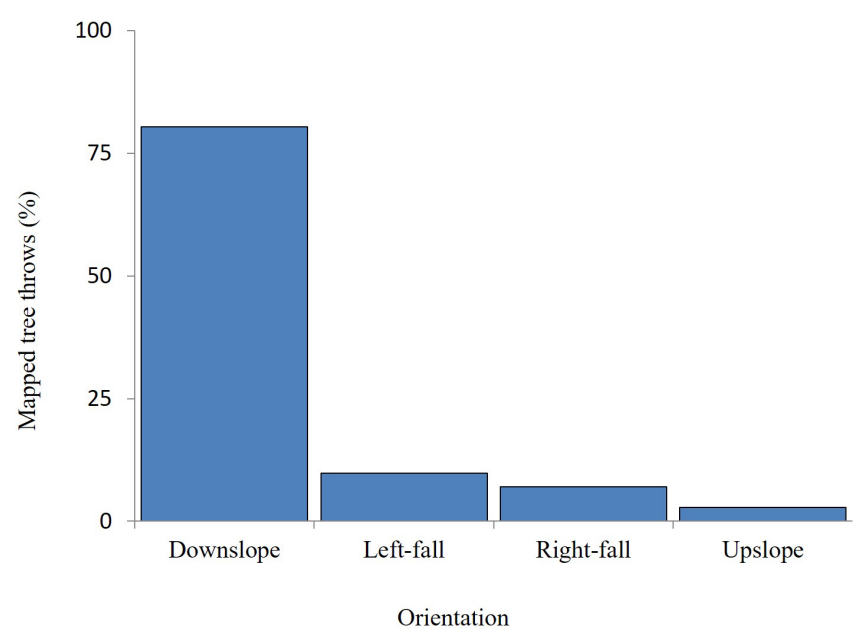

Figure 6. Tree throw fall directions categorized into four general orientations.

placing fine sediment (Martin et al., 2013), which include the disturbance of surface material by water-driven processes such as rain-splash (Gallaway et al., 2009) and raindrop impaction (Kinnell, 2005), freeze-thaw processes, and bioturbation by animals.

Assuming a similar rate of sediment migration through time by soil creep, rain-splash, impacting raindrops (Kinnell, 2005), and other water-related processes (Gallaway et al., 2009), and ignoring the influence that colonizing vegetation may have on stabilizing soil, our findings imply that a $50 \mathrm{~cm}$ tall mound could feasibly persist in the landscape for several centuries, although this could underestimate their true longevity, given that tree throw mounds will become increasingly stable as material becomes compacted and rooted vegetation binds particles and aggregates together. Despite this latter caveat, with regard to their possible persistence, our findings generally corroborate the predicted longevity of tree throw mounds in temperate forests originally proposed by Lutz (1940), reiterated by Putz (1983), and more recently confirmed in a review by Šamonil et al. (2010). They do not support later findings reported by Šamonil et al. (2013), who found that some tree throw mounds can persist for millennia under certain conditions, such as on sandy soils where high infiltration of surface water presumably inhibits runoff generation and serves to prolong their preservation, or in biomes where the climate is predominantly dry (e.g. Šamonil et al., 2010).

Based on limited field-based evidence of pit and tree throw mound longevity in different forested settings, the degradation of such features was exploratorily modelled by Martin et al. (2013) on $1.0 \mathrm{~m}$ diameter mounds using diffusion coefficients of $0.1,0.01$, and $0.001 \mathrm{~m}^{2} \mathrm{a}^{-1}$, the results from which suggested pit and mound features could be eradicated within timescales of just a few years to ca. 150 years. Although their wide-ranging results using varying diffusion coefficients, albeit on mounds of similar diameters to those investigated here, prevent us from drawing direct comparisons in terms of an actual erosion estimate, such as we report in this study, we pragmatically use field-based measurements of tree throw mound degradation reported in Martin et al. (2013) in which tree throw mound height diminished by an estimated $600 \mathrm{~mm}$ over a 30-year period. This represents an equivalent average erosion rate of $20 \mathrm{~mm} \mathrm{a}^{-1}$, which is an order of magnitude higher than the $2.1 \mathrm{~mm} \mathrm{a}^{-1}$ rate reported by us.

Given the variable results from different studies, more indepth information of tree throw mound formation, and the timescales over which denudation take place, is clearly required in order to provide a reliable base from which future modelling or similar studies might be conducted. Taking the number of mapped tree throws, and attributing a nominal $1.0 \mathrm{~m}$ diameter to the base of each tree throw mound, we calculate that disturbance to the surface soil by tree throw accounts for $0.0063 \%$ of the area of the Ibach River valley. This is a similar order of magnitude to that reported by both Osterkamp et al. (2006) and Gallaway et al. (2009).

\subsection{Variations in tree throw density}

In order to explore which characteristics most influenced sediment transport rates in our study area, multiple regression 
analysis was performed at the $95 \%$ confidence level on what were considered to be four key controlling variables: namely average root plate volume, average hillslope gradient, average tree throw direction, and tree throw density at each site. Results from multiple regression analyses are shown in Eq. (5):

$y=-4.74+9.70 x_{1}+0.09 x_{2}-0.03 x_{3}-0.002 x_{4}$,

where $y$ is the sediment transport rate, $x_{1}$ is average root plate volume, $x_{2}$ is average slope gradient, $\mathrm{x}_{3}$ is average tree throw direction, and $x_{4}$ is tree throw density. The results seen in Eq. (5) show a coefficient of determination $\left(r^{2}\right)$ of 0.84 $(84 \%)$ and also indicate that average root plate volume $\left(x_{1}\right)$ represents the only variable that significantly influences sediment transport, since data output for the other three variables, $x_{2-4}$, are all close to zero. A possible reason for the importance of root plate volume in influencing sediment transport may be due to the thin $(<40 \mathrm{~cm}$ deep $)$ soil profile, as this constraint typically forces trees to preferentially spread roots laterally across the soil profile in order to compensate for the lack of anchorage usually obtained through deeper root penetration (Nicoll et al., 2005; Gallaway et al., 2009). Exploring this possibility further, the average root plate depth of tree throws at each mapped site was correlated against the number of fallen trees per site using a Pearson correlation test, again, performed at the $95 \%$ confidence level. A significant indirect relationship between the two variables (Pearson $r=-0.552$; $P<0.05 ; n=12$ ) indicated that tree throws were more common at sites where root depth was shallow. As mapped tree throw sites were of unequal areas, average root plate depth for each site was correlated against the number of equivalent tree throws per hectare. The result of this additional test, again performed at the $95 \%$ confidence level, revealed no significant relationship between the two variables. Despite the lack of a significant relationship, and by way of explanation, however, we cautiously posit that applying the statistical approach at the hectare scale may possibly mask the effect of localized, or small-scale, variations in soil profile depth. However, this supposition would need to be corroborated in future studies by excavating soil pits at relevant locations to determine soil profile depth.

As almost $50 \%$ of mapped tree throws in our 12 study sites were between 31-50 years old at the time upheave occurred (Fig. 5), we surmise that trees of this age group and older probably reach a critical threshold in terms of their height, mass, and centre of gravity (Ramos-Sharrón and MacDonald, 2007), which renders them susceptible, presumably to root failure on the steep, rocky terrain commonly found in the Kaltbrunnental catchment. The possibility of large numbers of trees in close proximity all experiencing sudden upheave was noted by Hellmer et al. (2015), who attributed the "clustering" effect to an apparent build-up of "susceptibility", caused by factors which, they surmise, include the density of trees in a given area, numbers of already deceased trees, localized slope gradient, and age, size, and predominant species type. A possible reason for this somewhat paradoxical finding may relate to the cascade effect noted by Hellmer et al. (2015), whereby tree throw often occurs in clusters, with many trees being upheaved in close proximity to each other.

\subsection{The effect of wind on tree throw}

The effect of wind on tree throw could not be statistically tested due to an absence of wind direction data at the necessary spatial and temporal resolutions and the likelihood that localized topography might also have influenced wind speed and direction by deflecting prevailing winds (e.g. Ruel et al., 1998). However, as the direction of tree failure during winddriven storm events tends to align with predominant wind direction (Gallaway et al., 2009), the fall angle of individual tree throws in this catchment was used as a proxy to indicate the role that prevailing winds may or may not have played in their upheave (see Ruel et al., 1998; Hellmer et al., 2015). In order to explore this possibility more thoroughly, GIS was used to determine hillslope aspect of the 12 surveyed areas, which were then sub-divided into four cardinal groups: namely north, south, east, and west. The fall direction of individual tree throws on each hillslope site (expressed in degrees) was then determined, again with $0^{\circ}$ representing the most direct downslope route to the river and $180^{\circ}$ representing directly upslope. This approach, which can be seen in Fig. 7, followed the rationale that if fall direction was initiated or controlled by prevailing winds during Storms Lothar and Martin, the orientation of all fallen trees would be generally similar.

Interrogating data presented in Fig. 7 more closely reveals that notable numbers of tree throws fell at an angle of $0^{\circ}$ or directly downslope towards the Ibach River (Table 4). In terms of absolute numbers, fallen trees situated on eastfacing hillslopes recorded the highest proportion at $32 \%$ (21; $n=70)$, followed by the north-facing slopes at $29 \%$ (10; $n=34)$, and $20 \%(15 ; n=75)$ on west-facing slopes. The exception to this general trend was on south-facing slopes where only $8 \%$ (3) of all mapped tree throws $(n=36)$ fell at $0^{\circ}$. If the range of fall direction is expanded to between $345-20^{\circ}$, however, $66.5 \%(143 ; n=215)$ of all mapped tree throws fell towards the river (i.e. directly downslope), irrespective of the hillslope aspect on which they were located. These findings not only cause us to question whether individual high-magnitude storms, such as Lothar and Martin, acted as a trigger in initiating tree throw, certainly in this particular catchment (see Bründl and Rickli, 2002), but also open up the possibility that root failure leading to tree throw could actually be initiated by relatively low-magnitude storm events which take place more regularly.

Although somewhat anecdotal, the above possibility is supported by ca. 150 separate site visits undertaken by the first author (Greenwood) over a ca. 6-year period, where it 


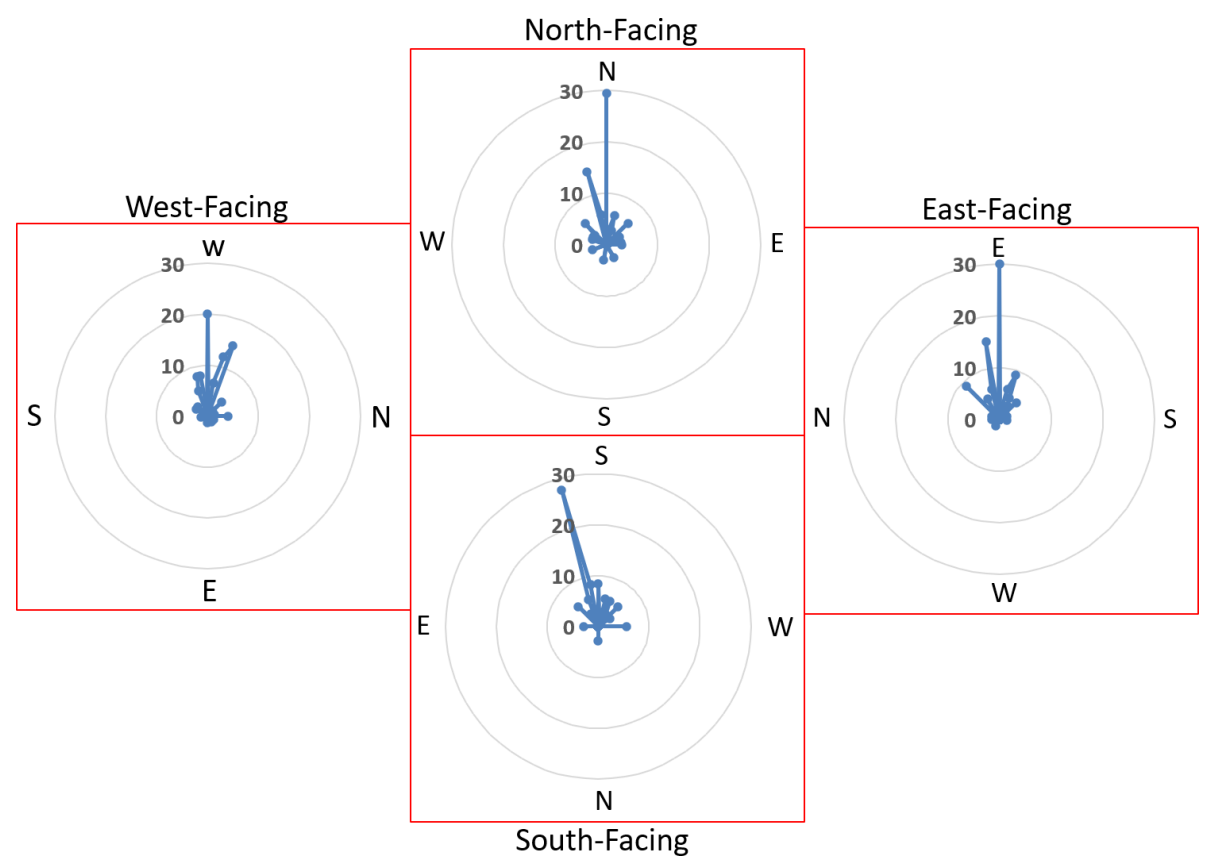

Figure 7. Percentage proportions of individual tree throw fall directions, relative to the four main hillslope aspects; north (N), south (S), east (E), and west (W), on which they were mapped.

Table 4. Numbers of tree throws falling at $0^{\circ}$, expressed as percent of total number of tree throws, relative to the hillslope aspect on which they were mapped.

\begin{tabular}{lrrr}
\hline $\begin{array}{l}\text { Hillslope } \\
\text { aspect }\end{array}$ & $\begin{array}{r}\text { Total tree } \\
\text { throw numbers }\end{array}$ & $\begin{array}{r}\text { Tree throw } \\
\text { falling } 0^{\circ}\end{array}$ & $\begin{array}{r}\text { Tree throw } \\
(\%)\end{array}$ \\
\hline North & 34 & 10 & 29 \\
South & 36 & 3 & 8 \\
East & 70 & 21 & 30 \\
West & 75 & 15 & 20 \\
\hline Total & 215 & 49 & 23 \\
\hline
\end{tabular}

was observed that tree throw in this catchment seemed to operate as an almost quasi-continuous process, irrespective of whether a high-magnitude storm had occurred or not. In light of previous research demonstrating that $30 \%$ less force is required to induce downslope root failure than equivalent upslope root failure (Nicoll et al., 2005), we tentatively attribute the prevalent downslope fall direction to a reduction in root anchorage. Whilst a lack of data on specific wind direction means that upheave by wind during single, high-magnitude storm events, such as Lothar or Martin, cannot be entirely dismissed, we hypothesize that the presence of bedrock close to the surface of steeper slopes combined with a shallow soil profile (Lutz, 1940; Mills, 1984; Ruel, 2000) may represent contributory factors to their upheave. From the frequent observations of recent upheaved trees, and based on our data, we further hypothesize, albeit tentatively, that perhaps once trees in this catchment attain a certain age, and hence, a certain size and height, the ability of the tree to remain upright and stable appears to be compromised (Gabet et al., 2003), to the point where the height and mass and raised centre of gravity associated with larger trees all render them vulnerable to upheave (Rich et al., 2007).

\subsection{Sediment transport rates: a comparison with other relevant studies}

Table 5 lists key findings from three similar studies for the purpose of comparing and contrasting equivalent values obtained in this investigation, although we acknowledge that their sediment transport estimates include both fine and coarse sediment. With regard to the spatial extent of study sites, despite our investigation surveying the smallest area (cumulative $5.3 \mathrm{ha}$ ), and mapping the lowest total number of tree throws (215), we recorded the highest average equivalent tree throw density per hectare (Table 2). Given that $>70 \%$ of mapped tree throws in our river valley were $\geq 31$ years old at the time upheave occurred, the larger stature associated with more mature trees suggests, again, that they probably reach a critical threshold in terms of their height and mass, which when exceeded, renders them vulnerable to root failure, whereupon upheave can occur. We tentatively attribute this possibility to the characteristically steep hillslopes in our study catchment, where steeply convex slopes and the presence of bedrock close to the surface exert a control that is proportional to sediment flux, which constrains the depth of the soil profile, as initially reported by Dietrich et al. (1982) and 
Table 5. A comparison of key findings from four similar tree throw studies. It should be noted, however, that estimated sediment transport in this investigation only includes data for the fine-sediment fraction and therefore likely underestimates actual sediment transport.

\begin{tabular}{lrrrr}
\hline & $\begin{array}{r}\text { Gallaway et } \\
\text { al. (2009) }\end{array}$ & $\begin{array}{r}\text { Hellmer et } \\
\text { al. (2015) }\end{array}$ & $\begin{array}{r}\text { Strzyżowski } \\
\text { et al. (2018) }\end{array}$ & $\begin{array}{r}\text { This investi- } \\
\text { gation (2018) }\end{array}$ \\
\hline Modelled time since tree throw event (a) & 32 & 20 & 48 & 18 \\
Area mapped/surveyed (ha) & 9.8 & 108 & 21,160 & 5.3 \\
No. of mapped tree throws & 319 & 643 & 252 & 215 \\
Tree throw density (ha ${ }^{-1}$ ) & 33 & 6 & 0.01 & 43 \\
Fine sediment as proportion of total root plate (\%) & $0-75$ & $25-50$ & 100 & 25 \\
Estimated sediment transport rate $\left(\mathrm{m}^{3} \mathrm{~m}^{-1} \mathrm{a}^{-1}\right)$ & $1.2 \times 10^{-3}$ & $2.3 \times 10^{-5}$ & $2.76 \times 10^{-5}$ & $2.7 \times 10^{-5}$ \\
\hline
\end{tabular}

more recently confirmed by Heimsath et al. (1997) and Gabet and Mudd (2010). Topographic characteristics may therefore explain why upheaved trees $\geq 71$ years old only accounted for $4.7 \%(n=10)$ of our mapped tree throw dataset.

In terms of annual sediment transport rates, three studies calculated values on the order of $10^{-5} \mathrm{~m}^{-1} \mathrm{a}^{-1}$ (Table 5). The exception to this was Gallaway et al. (2009), who recorded transport rates on the order of $10^{-3} \mathrm{~m}^{-1} \mathrm{a}^{-1}$. However, this discrepancy may be explained by the fact that their study focused on tree throw in a post-wildfire area, which would have also removed the understorey vegetation, leaving the soil bare and unprotected against erosion. As slope gradient, fall direction, and sediment generation volumes documented in their investigation were comparable with the three other studies listed in Table 5, reasons for their notably higher rate of transport are unclear, but may have arisen due to the integration of a complex modelling component dealing with tree population dynamics. Noteworthy between the four studies, however, are differences in estimates of the proportion of fine sediment associated with total root plate volume. Despite Gallaway et al. (2009) determining the proportion on a case-by-case basis in increments ranging from $0 \%-75 \%$, estimates from the four studies range from a liberal $100 \%$ (Strzyżowski et al., 2018) to a cautious 25\% (this study). As the proportion of fine sediment estimated by us represents the most conservative of the four values, our preliminary assessment of sediment generation rates may be overly cautious, and hence transport rates may be underestimated, the likelihood of which is further elevated since the coarse-sediment fraction was not included in our calculations.

\section{Conclusion}

The results from this preliminary assessment of sediment generation potential by tree throw and the subsequent degradation of tree throw mounds in a small river valley of the Jura Mountain range suggest that both mechanisms represent an important driver of hillslope processes that warrant more detailed investigation. Information on surface hydrology characteristics of four fresh tree throw mounds revealed high sediment yields and very high equivalent SSC values over a $24 \mathrm{~d}$ monitoring period, despite the fact that percent runoff coefficients were exceptionally low. Collectively, these findings are interpreted as evidence that degradation processes other than surface runoff are more dominant in eroding fresh tree throw mounds. Reasons for this are attributed to the loose, uncompacted nature of the material from which fresh tree throw mounds are formed, the characteristics of which are thought to promote infiltration of surface water, which inhibits runoff generation. Based on the average $0.14 \mathrm{~mm}$ denudation rate recorded by us over the $24 \mathrm{~d}$ period, equivalent to $2.1 \mathrm{~mm} \mathrm{a}^{-1}$, we estimate that a $500 \mathrm{~mm}$ high tree throw mound could theoretically persist in this catchment for around 200-250 years. However, as this value has been derived by ignoring the stabilizing influence of vegetation on soil mounds, future work would focus on monitoring a wider age range of soil mounds with varying vegetation cover.

For logistical and practical reasons, we did not estimate the coarse sediment fraction for the root plate of each mapped tree throw. Consequently, the $25 \%$ proportion of fine sediment attributed by us may underestimate the actual total sediment disturbance if all size fractions were included. Given this potential shortcoming in our investigative methodology, a more comprehensive approach in future would be to determine the proportions of both coarse- and fine-sediment fractions for an individual tree throw on a case-by-case basis, in order to obtain a more representative estimation that takes into account total sediment disturbance. For the finesediment fraction $(<2 \mathrm{~mm}$ dia.), however, tree throws detached and thus generated a total of $20.1 \mathrm{~m}^{3}$ or the equivalent of $3.8 \times 10^{-4} \mathrm{~m}^{3} \mathrm{~m}^{-2}$.

The process of tree throw was originally attributed to two extreme weather events that occurred in west and central Europe in late December 1999. Taking the 18-year period since both storms, this represents an annual sediment transport rate of $2.7 \times 10^{-5} \mathrm{~m}^{3} \mathrm{~m}^{-1} \mathrm{a}^{-1}$. Despite originally attributing all tree throws to Storms Lothar and Martin, based on tree throw fall direction, our interpretations of the available data suggest that their orientation was generally independent of hillslope aspect for the majority of fallen trees that we were able to map. Consequently, the original assumption that Storms Lothar and Martin played a major role in initiating tree throw 
may be incorrect but cannot be entirely dismissed without the benefit of historic localized wind direction data, which are not available. Instead, given the number of high-density areas of tree throws in this river valley, their relative maturity (average age 41 years), and the fact that tree throw tended to occur in clusters, we believe that groups of trees within a certain age range may become susceptible to upheave. Reasons for this heightened susceptibility may be related to the larger stature associated with older trees, which gradually renders them increasingly unstable and eventually compromises their ability to remain securely anchored on the inherently steep slopes where the soil profile is shallow. The possibility exists, therefore, that some trees are essentially primed to undergo upheave, and upheave could ultimately be initiated by frequent yet relatively low-magnitude storms.

Data availability. The paper is based on the master's thesis written by Jan Bauer. The thesis (signature: GEO Per 226 Bauer), including all data presented in the paper, can be retrieved from the Geoscience Library of the University of Basel, Switzerland.

Author contributions. PG conceived the project, PG and JB undertook fieldwork, JB undertook data analysis, and PG and NJK both contributed to interpreting, writing, and correcting the manuscript.

Competing interests. The authors declare that they have no conflict of interest.

Disclaimer. Publisher's note: Copernicus Publications remains neutral with regard to jurisdictional claims in published maps and institutional affiliations.

Acknowledgements. The authors thank A. Hügli and B. Thommen, the Bürgergemeinde (community mayors) from the towns of Brislach (Canton Basel-Land) and Himmelried (Canton Solothurn), respectively, for granting access to the study catchment, and Vincent Schneider for creating Fig. 1. We also thank the two anonymous reviewers for their thoughtful comments and suggestions which served to strengthen and improve the paper.

This study was funded by the Physical Geography and Environmental Change Research Group, Department of Environmental Sciences, University of Basel.

Review statement. This paper was edited by Cristian Scapozza and reviewed by two anonymous referees.

\section{References}

Bobrovsky, M. V. and Lyko, S. V.: Patterns of pedoturbation by tree uprooting in forest soils, Russ, J. Ecosyst. Ecol., 1, 1-22, https://doi.org/10.21685/2500-0578-2016-1-3, 2016.

Bründl, M. and Rickli, C.: The storm Lothar 1999 in Switzerland - an incident analysis, For. Snow Landsc. Res., 77, 207216, https://www.dora.lib4ri.ch/wsl/islandora/object/wsl:15318 (last access: 5 July 2021), 2002.

Burnand, J.: Waldgesellschaften und Waldstandorte im Kanton Basel-Land, Reinach, 38-235, 1990 (in German).

Constantine, J. A., Schelhaas, M.-J., Gabet, E., and Mudd, S. M.: Limits of windthrow-driven hillslope sediment flux due to varying storm frequency and intensity, Geomorphology, 175-176, 66-73, https://doi.org/10.1016/j.geomorph.2012.06.022, 2012.

Denny, C. and Goodlet, J.: Micro-relief resulting from fallen trees. Surficial Geology and Geomorphology of Potter County, United States Geological Survey (USGS), Pennsylvania, Professional Paper, 288, 59-66, 1956.

Dietrich, W., Dunne, T., Humphrey, N. F., and Reid, L. M.: Construction of sediment budgets for drainage basins, in: Sediment budgets and routing in forested drainage basins, edited by: Swanson, F. J., Janda, R. J., Dunne, T., and Swanston, D. N., USDA For. Serv. Gen. Tech. Rep. PNW-141, 1982.

EQE Consulting: EQE Summary Report: The European Storms Lothar and Martin, 26-28 December 1999, EQE International Consulting: Strategic Advisors for Natural Hazards and Terrorism, available at: https://docplayer.net/amp/11752424 Eqe-summary-report-the-european-storms-lothar-and-martindecember-26-28-1999.html, last access: 6 July 2021.

Evarham, E. M. and Brokaw, N. V. L.: Forest damage and recovery from catastrophic wind, Bot. Rev., 62, 113-185, https://doi.org/10.1007/BF02857920, 1996.

Fryirs, K. A., Brierly, G. J., Preston, N. J., and Kasai, M.: Buffers, barriers and blankets: The (dis)connectivity of catchment-scale sediment cascades, Catena, 70, 49-67, https://doi.org/10.1016/j.catena.2006.07.007, 2007.

Gabet, E. J. and Mudd, S. M.: Bedrock erosion by root fracture and tree throw: a coupled biogeomorphic model to explore the humped soil production function and the persistence of hillslope soils, J. Geophys. Res., 115, 1-14, https://doi.org/10.1029/2009JF001526, 2010.

Gabet, E. J., Reichman, O. J., and Seabloom, E. W.: The effects of bioturbation on soil processes and sediment transport, Annu. Rev. Earth. Planet Sci., 31, 249-273, https://doi.org/10.1146/annurev.earth.31.100901.141314, 2003.

Gallaway, J. M., Martin, Y. E., and Johnson, E. A.: Sediment transport due to tree root throw: integrating tree population dynamics, wildfire and geomorphic response, Earth Surf. Proc. Land., 34, 1255-1269, https://doi.org/10.1002/esp.1813, 2009.

Geißler, C., Kühn, P., Böhnke, M., Bruelheide, H., and Scholten, T.: Splash erosion potential under tree canopies in subtropical SE China, Catena, 91, 85-93, https://doi.org/10.1016/j.catena.2010.10.009, 2012.

Greenwood, P. and Kuhn, N. J.: Does the invasive plant, Impatiens glandulifera, promote soil erosion along the riparian zone? An investigation on a small watercourse in northwest Switzerland, J. Soils Sediments, 14, 637-650, https://doi.org/10.1007/s11368013-0825-9, 2014. 
Greenwood, P. and Zhang, Y.: Comparing grain size composition of inter-rill and rill-eroded sediment from cultivated hillslope soils using caesium-134 and cobalt-60 as tracers, Soil Till. Res., 198, 104532, https://doi.org/10.1016/j.still.2019.104532, 2020.

Greenwood, P., Baumann, P., Pulley, S., and Kuhn, N. J.: The invasive alien plant, Impatiens glandulifera (Himalayan Balsam), and increased soil erosion: causation or association?: case studies from a river system in Switzerland and the UK, Special Issue 14th International Association of Sediment Water Sciences, J. Soils Sediments, 18, 3463-3477, https://doi.org/10.1007/s11368-018-2041-0, 2018.

Greenwood, P., Gange, A. C., and Kuhn, N. J.: Evidence of sedimentation inequality along riparian areas colonised by Impatiens glandulifera (Himalayan Balsam), Weed Res., 60, 26-36, https://doi.org/10.1111/wre.12397, 2019.

Hayhoe, H. N., Pellatier, R. G., and Van Vliet, A. J. P.: Estimation of snowmelt runoff in the Peace River region using a soil moisture budget, Can. J. Soil Sci., 73, 489-501, https://doi.org/10.4141/cjss93-050, 1993.

Heimsath, A. M., Dietrich, W. E., Nishiizumi, K., and Finkel, R. C.: The soil production function and landscape equilibrium, Nature, 388, 358-361, https://doi.org/10.1038/41056, 1997.

Hellmer, M. C., Rios, B. A., Ouimet, W. B., and Sibley, T. R.: Ice storms, tree throws, and hillslope sediment transport in northern hardwood forests, Earth Surf. Proc. Land., 40, 901-912, https://doi.org/10.1002/esp.3690, 2015.

Horowitz, A. J., Stephens, V. C., Elrick, K. A., and Smith, J. J.: Concentrations and annual fluxes of sediment associated chemical constituents from conterminous UK coastal rivers using bed sediment data, Hydrol. Process., 26, 1090-1114, https://doi.org/10.1002/hyp.8437, 2012.

Kinnell, P. I. A.: Raindrop-impact-induced erosion processes and prediction: a review, Hydrol. Process., 19, 2815-2844, https://doi.org/10.1002/hyp.5788, 2005.

Ledermann, T., Herweg, K., Liniger, H., Schneider, F., Hurni, H., and Prasuhn, V.: Erosion damage mapping: Assessing current soil erosion damage in Switzerland, edited by: Dazzi, C. and Costantini, E., Adv. GeoEcol., 39, ISBN 978-3-923381-56-2, 2008.

Lutz, H. J.: Disturbance of forest soil resulting from the uprooting of trees, Yale University, School of Forestry Bulletin No. 45, Yale University, New Haven, CT, 1-37, 1940.

Martin, Y. E., Johnson, E. A., and Chaikina, O.: Interplay between field observations and numerical modelling to understand temporal pulsing of tree root throw processes, Canadian Rockies, Canada, Geomorphology, 200, 89-105, https://doi.org/10.1016/j.geomorph.2013.04.017, 2013.

Martin, Y. M.: Modelling hillslope evolution: linear and nonlinear transport relations, Geomorphology, 34, 1-21, https://doi.org/10.1016/S0169-555X(99)00127-0, 2000.

Meteoblue: Climate Grellingen, available at: https://www. meteoblue.com/en/weather/historyclimate/climatemodelled/ grellingen_switzerland_2660513, last access: 29 May 2021.

Mills, H. H.: Effect of hillslope angle and substrate on tree tilt, and denudation of hillslopes by tree fall, Phys. Geogr., 5, 253-261, https://doi.org/10.1080/02723646.1984.10642257, 1984.

Mitchell, A. F.: A Field Guide to the Trees of Britain and Northern Europe, Collins Publishers, London, 1974.
Mitchell, S. J.: Wind as a natural disturbance agent in forests: a synthesis, Forestry, 86, 147-157, https://doi.org/10.1093/forestry/cps058, 2013.

Nicoll, B. C., Achim, A., Mochan, S., and Gardiner, B. A.: Does steep terrain influence tree stability? A field investigation, Can. J. Forest Res., 35, 2360-2367, https://doi.org/10.1139/x05-157, 2005.

Norman, S. A., Schaetzl, R. J., and Small, T. W.: Effect of slope angle on mass movement by tree uprooting, Geomorphology, 14, 19-27, https://doi.org/10.1016/0169-555X(95)00016-X, 1995.

Osterkamp, W. R., Toy, T. J., and Lenart, M. T.: Development of partial rock veneers by root throw in a subalpine setting, Earth Surf. Proc. Land., 31, 1-14, https://doi.org/10.1002/esp.1222, 2006.

Pawlik, Ł.: The role of trees in the geomorphic system of forested hillslopes - A review, Earth-Sci. Rev., 126, 250-265, https://doi.org/10.1016/j.earscirev.2013.08.007, 2013.

Pawlik, Ł., Migoń, P., and Szymanowski, M.: Local- and regional-scale biodynamics due to tree uprooting in seminatural and managed montane forests of the Sudetes Mountains, Central Europe, Earth Surf. Proc. Land., 41, 1250-1265, https://doi.org/10.1002/esp.3950, 2016.

Putz, F.: Treefall pits and mounds, buried seeds, and the importance of soil disturbance to pioneer trees on Barro Colado Island, Panama, Ecology, 64, 1069-1074, https://doi.org/10.2307/1937815, 1983.

Ramos-Sharrón, C. E. and MacDonald, L. H.: Measurement and prediction of natural and anthropogenic sediment sources, St John, U.S. Virgin Islands, Catena, 71, 250-266, https://doi.org/10.1016/j.catena.2007.03.009, 2007.

Rich, R. L., Frelich, L. E., and Reich, P. B.: Wind-throw mortality in the southern boreal forest: effects of species, diameter and stand age, J. Ecol., 95, 1261-1273, https://doi.org/10.1111/j.13652745.2007.01301.x, 2007.

Roering, J. J., Marshall, J., Booth, A. M., Mort, M., and Jin, Q.: Evidence for biotic controls on topography and soil production, Earth Planet Sc. Lett., 298, 183-190, https://doi.org/10.1016/j.eps1.2010.07.040, 2010.

Ruel, J.-C.: Factors influencing windthrow in balsam fir forests: from landscape studies to individual tree studies, Forest Ecol. Manag., 135, 169-178, https://doi.org/10.1016/S03781127(00)00308-X, 2000.

Ruel, J.-C., Pin, D., and Cooper, K.: Effect of topography on wind behaviour in a complex terrain, Forestry, 71, 261-265, https://doi.org/10.1093/forestry/71.3.261, 1998.

Šamonil, P., Král, K., and Hort, L.: The role of tree uprooting in soil formation: a critical literature review, Geoderma, 157, 6579, https://doi.org/10.1016/j.geoderma.2010.03.018, 2010.

Šamonil, P., Scheatzl, R. J., Valtera, M., Goliáš, V., Baldrian, P., Vašíšková, I., Adam, D., Janík, D., and Hort, L.: Crossdating of disturbances by tree uprooting: Can three throw microtopography persist for 6000 years?, Forest Ecol. Manage., 307, 123-135, https://doi.org/10.1016/j.foreco.2013.06.045, 2013.

Schaetzl, R. J., Burns, S. F., Johnson, D. L., and Small, T. W.: Tree uprooting: review of impacts on forest ecology, Vegetatio, 79, 165-176, https://doi.org/10.1007/BF00044908, 1988.

Schweingruber, F. H.: Wood Structure and Environment, Springer Series in Wood Science, Springer Publishing, Heidelberg, 2007. 
Strzyżowski, D., Fidelus-Orzechowska, J., and Żelazny, M.: Sediment transport by uprooting in the forested part of the Tatra Mountains, southern Poland, Catena, 160, 329-338, https://doi.org/10.1016/j.catena.2017.09.019, 2018.
Walling, D. E., Owens, P. E., Carter, J., Leeks, G. J. L., Lewis, S., and Mehard, A. A.: Storage of sediment-associated nutrients and contaminants in river channel and floodplain systems, Appl. Geochem., 18, 195-220, https://doi.org/10.1016/S08832927(02)00121-X, 2003. 